\title{
Political Borders Are Not Natural Orders - The COVID-19 Pandemic in Frankfurt on the Main and Its Refugees
}

\section{Homayun Alam}

$\mathrm{PhD}$, Independent Researcher, Frankfurt on the Main, Germany

\section{Abstract}

The overall aim of this paper will be to stick to the previous researchers to get valid and impartial data from the most international city of Germany: Frankfurt on the Main. However, this research paper will try to provide answers by comparing war situations (object) where curfews are at daily basis impact on lives of people, who become gradually refugees (subject). In the recent years many refugees found their way to the global city of Frankfurt and its region of Rhine-Main. In these days if talking about the situation of the visible shutdown, lockdown and the strictly forbidden laws for an overall betterment of life, refugees have a tendency to explain to the native people about their crisis-laden past: "Resilience for Survival". Their recent past in the war-torn countries of Afghanistan, Syria, and Iraq in West-Asia, Libya in Africa or the many wars in the Balkans in the 1990s in Europe, are a case in point. Given that as a matter of fact, when individuals are leading conversations about the outbreak to the recent lockdown, especially, fugitives try to explain to the ordinary dweller of Frankfurt through what life-threatening circumstances they experienced. This described social encounter despite the imposed social distancing is the proof how our glocalized planet (global and local) effects the everyday life and every human being lives in each and every corner of the confined nation-states.

Keywords: transnationality, refugees, migration, everyday life, Frankfurt on the Main

\section{Introduction}

The city of Frankfurt on the Main is rooted in the Rhine-Main area. It is economically or historically not only one of the most affluent regions of Germany, but it is also embedded at the center of Europe. Frankfurt is by far the most international city of Germany. In a survey Frankfurt could prove to be a "global city", having a "super diversity" and being totally "transnational" (Vertovec, 2013). This is a proof why Frankfurt is chosen by many global actors not only in the prominent domain of finance and money as a hub. One important fact to point out is the skyline of Frankfurt and 
one of its dominant founders. The skyline of Frankfurt was much internationalized in the mid-1970s by an Iranian migrant, called Ali Selmi. He established his firm shortly after the Second World War. Frankfurt as a hub for finance and trade (like the Frankfurt stock exchange and trade fairs) has its roots in the medieval time period (Holtfrerich, 1999). In addition, it was chosen for example in the recent years and decades by Chinese banks, Korean car companies and Indian IT-entrepreneurs as one of their explicit global bases. This is the one and only face ordinary people might know about this city. The other face of Frankfurt will be explored on grounds of the Covid19 pandemic outbreak in this article, when it comes to the status of refugees, especially from Afghanistan, Syria, and Iraq.

For that reason, Frankfurt is directing its refugees through a division of tasks: accommodation, integration and public (Stadt Frankfurt am Main, 2020a). Each of these three categories has subdivisions that guides a refugee precisely through a process of search, finding and monitoring by the municipality staff as well as volunteers if necessary.

In intellectual terms Frankfurt belongs to the networking of "City of Refuge" (ICORN, 2006). Since 1997 under the supervision of the municipality threatened writers are invited to live with a scholarship for two years in the city of Frankfurt. Additionally, Frankfurt is the city of books, whose annual book fair is the biggest of its genre in Germany and in Europe. The Frankfurt Institute for Social Research (Frankfurt School) is going to turn a century, established in 1923 by Felix Weil (Wiggershaus, 2008). In this eminent institution masterminds such as Theodor Adorno, Max Horkheimer, Herbert Marcuse, Erich Fromm, Walter Benjamin and Juergen Habermas were of the first in the 20 $0^{\text {th }}$ century to explore about the society through the lens of Marx thoughts and others. Another figure is Anne Frank, who is often mistakenly perceived as Dutch. She was born and raised during her shirt lifetime in Frankfurt, but migrated due to the Nazi threat with her parents after some years to the Netherlands (Jüdische Orte in Frankfurt am Main, 2011). Historically, in the 19 century the celebrity of German poets, Johann Wolfgang von Goethe, was born in Frankfurt and spent a great part of his lifetime in the city. Today, the biggest University of Frankfurt, Goethe-University, carries his name. This city is not only in the heart of the Rhine-Main region, the Federal Republic of Germany and the European continent, it had since the medieval period the status of an imperial free city (Historisches Museum Frankfurt, 2020).

Despite all this beyond belief facts about Frankfurt, this city suffered in the $19^{\text {th }}$ century from the cholera pandemic narrated by the "Corona-Special Virtual Tour" (Setzepfandt, 2020): As late as the year of 1830 the cholera disease infection took the life of many people in Frankfurt, so the solution was cremation.

Later on, after the French Revolution, Frankfurt gained again its status as a free city. Subsequently, it became in 1848-49 the seat of the first German parliament at St. Paul's Church. In 1866 Frankfurt had been annexed by the Prussians from Berlin that 
marked the loss of its political independence. After the Second World War in the 20 ${ }^{\text {th }}$ century, it was foreseen to recuperate Frankfurt "again" the German seat of decision makers. Then, Bonn became by four votes the political capital until the fall of the Berlin wall (Deutscher Bundestag, 2014). Shortly after the Second World War, it was intended that the present-day headquarter of the Hessian broadcasting corporation should become the Federal Parliament of Germany.

Critically, another fact about the city is the negative domestic reputation of Frankfurt. As the fifth major city of Germany it has the most important national airport, Germany's and even Europe's historical largest railway station in the newrenaissance style, and the A5 as one of the most important Germany highway, to provide references about few leading points. On international level, Frankfurt is the center for economy, finance and trade: Each criminal act as counted, passes its way through the Frankfurt police, then as a consequence to the public prosecution department and finally to the Frankfurt court of justice. These additional factors are the primary causes for the one and single reason of the negative collected statistics, when it comes to the status of Frankfurt being the most criminal city in Germany (Polizeiliche Kriminalstatistik, 2018).

The "Homo Migrant" is the stereotype of human being, who is populating, influencing, and thus enriching Frankfurt, as a repeated center in each and every imagineable field.

\section{Methodology}

The data gathered for this research is based on qualitative research methods. For this purpose, the researcher employed an in-depth interview guide and observation technique to gather research data. The sample included 28 refugees aged between 1855 years from Afghanistan, Syria, and Iraq. In general terms Frankfurt has according to its own municipality as of March 2020, 34\% Afghan, 16\% Syrian and 5\% Iraqi refugees out of 4.467 refugees of whom two third are male and one third female (Stadt Frankfurt am Main, 2020b). For this study they were selected through verified asking concerning differences in their mother tongues, ethnic and city belongings, and life experience in Frankfurt. Researcher sustained a gender balance in the sample size of this research. Therefore, in this observation, 18 male and 11 female respondents were met at different public spaces. Not a single person of the target respondents was known before. The researcher maintained a certain trust level with the respondents without any difficulty and convinced them to do a detailed interview. However, participants did talk much about many aspects of their lives in such gatherings to some extent, because of the abruptly lockdown process. The data collection was carried out through IDIs at public spaces in the neighborhood of the researcher in Frankfurt. For this research, the concerned data was collected during the time of the lockdown in Frankfurt from mid-March 2020 to the mid-April 2020. 


\section{Objectives}

1. To explore the factors which are responsible for the resilient habits of the refugees in Frankfurt in times of Covid-19 pandemic.

2. To understand the transnational resilience in and outside the fugitive community, which influences their everyday life and shapes their identity.

\section{Discussion and Analysis}

The contemporary shutdown process was done in Frankfurt like in many other cities worldwide, as well. It was announced by the media, then the public reacted, and eventually the society has to follow orders of the imposed lockdown in general and social distancing in public space in particular.

In the first days in March 2020 people of all walks of life had not enough conscience about the scale of the Covid-19 pandemic and its severe hygienic impacts. By and large, people began to stockpile noodles and toilet paper. So, things changed rapidly not only by health measures, but by social-habitual, economical-income, or just the fear of lacking enough food in groceries. All these caused panic behavior for the individuals, families, and couples (Harari, 2020). Many domestic employees and foreign expats left Frankfurt to go back to their native home.

In fact, the entire process of everyday life was power cut. Within these limits, it was not much easy to talk to people. But, refugees in the neighborhood, streets, and groceries and in public spaces stood quite open without or let us say a smaller amount of panic. Those refugees from Afghanistan, Syria and Iraq showed not much panic fear by social distancing measures by standing in a queue to maintain a distance of 1.5 meters between each other. Or else, if one customer gazed on a product a refugee offered the man to take it at first, and often stated the two English words of "no problem" with a smile.

By the passage of time, it was quite obvious the Covid-19 pandemic outbreak caused death tolls in each and every country at large scale. A 27 year old Syrian refugee was concerned: "Sometimes I feel it was a mistake to migrate to Europe. With this current infectious diseases, the labor market, and housing problems I acutely want to get rid of this situation as soon as possible."

\section{Media Reports}

The German media was from the beginning on full of reports from experts such as the local medical advisors, the three principal virologists and the two German national research institutes. In all news outlets the topic of the hour was Covid-19 pandemic.

The public space played, as reported, a key role on daily basis in Frankfurt. Many young people could not attend gyms, schools, universities or workplaces. The solution was to find third ways to match with a new everyday life. The regional and local media of Hesse covered many streams of life to showcase under what circumstances ordinary people - loneliness, jobless, aged, single parents - do really suffer without 
sufficient protection (Hessenschau, 2020). For the short time period, politicians pledged to provide financial aid to vulnerable employees, households, and small shop owners.

In the meantime, it was reported for example in Greece that refugees from war-torn countries intend to travel to Western Europe, targeting as first destination Germany. In advance, the conscience about the Covid-19 pandemic raised at large scale among the native dwellers. In Frankfurt, as case in point, many refugees were mistreated at the Turkish-Greece frontier. After a while, the amount of deaths raised due to Covid19 pandemic infectious pace according to the principal public health institute in Germany (Robert Koch Institut, 2020). The Robert Koch Institute provided data from the third of March 2020 about diagnostic, hygiene and control of Covid-19 pandemic outbreak. As a result, the plight of the refugees at the eastern frontiers small continent of Europe was fully forgotten.

In Frankfurt, refugees have contacted their families, where they had in addition to the media coverage firsthand information about their home countries, cities, and the unending armed conflicts or wars. In this case a 51 year old woman from Iraq voiced: "In my age migration makes really not much sense. As you can imagine, I let my life behind me, came to here, only for the sake of autonomy, and to secure the future of my children."

\section{Refugees as Survival Actors}

In the year of 2015, as the German chancellor Angela Merkel opened the doors for refugees to find a proper shelter in Germany, many observers were critical if this deliberate act was the right approach to receive up to one million predominantly male refugees from war-torn countries (Katz, Noring, \& Garrelts, 2016). It was not clear by the very arrival of the refugees at that time with what kind of infectious diseases, like scabies and pediculosis, these ones will arrive in Germany (Alberer, Malinowski, Sanftenberg, \& Schelling, 2018).

However, in the time after Merkel was internationally valued as someone who practiced good will by her applied policies. At national level the German society was practicing a unique welcoming culture as a gesture by truthful words and deeds. After the incident of Cologne at New Year's Eve 2016 the hospitable frame of mind threatened to turn worse. The so-called celebrated welcoming culture was put in question. Especially, many male asylum seekers targeted Germany as final destiny, what caused hostile sentiments among Germany's news outlets and mass media (Georgiou, Zaborowski, 2017).

Within the years, especially in times of Covid-19 pandemic the daily survival as resilience by measures of hygiene practices are the most important precautions. In exactly this point, the lots of male refugees who came to Frankfurt are visible for their habits in public spaces. Hence, in many of participant observations since the outbreak of the virus refugees' showcase in conversations that they are used to with daily 
curfews due to armed conflicts in their native countries. A 19 year old Afghan lamented: "Look, I was born in Iran, stemming from Central Afghanistan, my face features are betraying myself by only a single second about my origin. My East Asian appearance betrayed myself as a foreigner, the Iranian government through their thugs were about to intimidate myself every day. My parents fled in the late 1990s from the Taliban to Iran. In Iran, which I consider still as my home, I was beaten as a street vendor in public, then I was not allowed to participate in public school. Please, answer my humble question: Do you really think I fear this virus?"

This source of dread interconnects with shortcomings of nutrition or education. In the same vein, the concept of identity is much touched: whether the nation, religion, patriarchy, nor the tribe are safeguards. As of now, refugees tend to explain the cause and reason of their escape from war zones to that of freedom.

Before the outbreak of Covid-19 pandemic wars, conflicts and refugees were perceived as a phenomenon from far away. Within this short period of time, refugees are not more or less valued as before by the domestic German welcoming culture, but the event of the current virus from Wuhan in China triggered being more sophisticated by glocalized (global and local) crisis: That is to say, local diseases in Asia impacts each and every socioeconomic life at wide-ranging global level.

Especially, in Frankfurt the language changed in social media. The discursive proverb of "social distancing" was replaced in these virtual public discussions by "physical distancing" and "social solidarity" was written in red letters. Particularly, these headings have to signify the importance of perhaps first-hand mores and values in times of crisis. In each street of every neighborhood the Frankfurt residents were accumulating aid for elder and vulnerable persons. A 30 year old male refugee from Syria indicated: "This social or physical distancing, call it as you like, is sophisticated. Nobody has beaten you up to be in line with these new habits to avoid contagion. Here is the matter of fact, the German police forces are talking to you in a friendly, calm and peaceful way, while in my home country a policeman alone is the symbol of menace."

Undeniably, daily life changed in many ways. If the concern of an ordinary person was about his or her lifestyle, work and gym, the present Covid-19 pandemic was about continued existence procedures. The short news on the smart phones were expressing about the death records in Frankfurt, Rhine-Main region, Germany, Europe and the entire planet earth. There was no way out to be ignorant about the sharp line between today's life and tomorrow's after life.

\section{Re-opening as Resilience}

After the shutdown procedure from the kickoff of the spring until mid-April 2020 the re-opening is a bargain. At first, the economy of a city like Frankfurt was hit relentlessly due to the thousands of retailers who lost their customers (Wirtschaftsförderung Frankfurt, 2020). Short after, a large number of employees lost their income sources (Hessenschau, 2020b). The short-term ultimate solution from 
responsible decision makers in politics was, if an employee lost livelihood, to do immediate work (German: Kurzarbeit). For many observers as medical experts a reopening was to be done carefully by monitoring agencies. The Frankfurt International Airport, the stock market, the fair and many other global acting businesses were to restart by an hourly loss of millions of Euros.

It came worse as president Trump of the USA with his "America First" populist rhetoric decided amidst a life-threatening virus not to fund anymore the World Health Organization like the US did it before (The White House, 2020). The German public opinion was even before the Corona crisis not much benign to the US leadership, its position vis-à-vis China, and its way to overcome the Comid-19 pandemic (Barkin, 2020). The epicenter of the outbreak changed within few weeks from China in Asia to New York in the USA. Earlier, it was transmitted from Asia to Europe, subsequently to Africa, which was hit rigorously by the outbreak of the virus.

Still, the ordinary refugee is not much touched by the great discourses in Frankfurt. There is no scientific investigation about refugees in Frankfurt how they would obey the rules, if experiencing or re-experiencing situations of crisis without arms. But, one 50 year old Iraqi refugee is expressing: "Iraq is a rich country by natural resources. This is not something new to hear, but for all that, since my adolescent life I have experienced how to survive, being more attentive about my surroundings, sharing everything I had in and out of my being."

Resilience for survival is not only a matter of fact, but in the same time it is how to act properly to safe on state level employments, to preserve socio-economic freedom, and to improve perhaps the labor state of affairs. Despite the fact that Covid-19 pandemic outbreak was not taken seriously by some states at the beginning of the year 2020 . Critically evaluated, it is time to reshape a new order for the glocalized economy, which should not be decided exclusively between the two major world leaders of China and the USA (Hamideh, 2018).

Gradually, public life is guaranteed throughout Germany by the expertise of virologists, if the physical and social distancing are going to be maintained. Once more, it is important to carry masks in public transportations, groceries and institutions for the simple reason not to spread individual breath.

For an ordinary refugee, who lives in a zone of freedom similar to in Frankfurt, it is very important to achieve legal documents, having an appropriate shelter or learning the native German language. Many male single refugees spent the vast part of their income for shared housing, which is in the case of Frankfurt around $€ 710$ (Bathke, 2019). Yet again, it is surprising in the eyes of a refugee that in times of a virus disease outbreak Frankfurt as a city has such a largely control, which is in comparison to their experience not violent, but considerably educative and preventive. In this regard a 45 year old male Afghan shares the opinion: "Frankfurt as a city is more competent than my entire country. The preventive actions taken to this point by the municipality to 
anticipate the appropriate reactions in these days and weeks are mind blowing. In Kabul I didn't know, if I will survive the day healthy by leaving home."

A re-opening in Frankfurt with his largest international airport, its national central railway station, the internationally orientated banks, just to remark few essential daily belongings of this "alpha global city", is too much contested (Lohde-Reiff, 2003).

\section{Foresight and Hindsight}

If resilience is the bottom line of the hour of Covid-19 pandemic by means of migration to carry on just life, so one should examine more the life of an average refugee to gain insights. In general, the foresight in war zones is to save the own and family's life. In particular, the hindsight is not to participate in warfare, or avoiding the choice being a member of one of the participant groups in an armed conflict. The domestic German welcome culture of the year 2015 high-raised the expectations of the average refugee on the grounds of accommodation, regular income source, and a better life: But, since then, refugees and asylum seekers live under nearly the same circumstances (Neis, Meier, \& Furukawazono, 2018).

Since Covid-19 pandemic outbreak the entire society is somehow getting more postheroic: People have a tendency to be more anxious. If before the virus a face was marked by sorrow, because the everyday life was against the low income, which resonates simply too many other factors for leading a suitable life. At this time, the yesterday's grief and despair is not getting into oblivion. But then again, this virus has become a struggle between life and death. As said by a 28 year old Syrian refugee: "I might be observing many aspects of life here in the West, which are not much clear to my own since my arrival of the year 2015 in Frankfurt. But, I do not come across the reason of the daily pressures of the native people. What is honestly the reason of their dissatisfaction? Has it something to do, excuse me for expressing this, that the state is paying low salaries and takes the great part of the average income for taxes?"

Therefore, the significance of solidarity to the next person converted to a virtue. As a consequence, helping the weak and aged people is even promulgated by the government, what a citizen is able to read in buildings, streets, and public transportation in Frankfurt. Similarly, other values like tolerance, acknowledgement for the so-called system relevant employees like scientists, medical doctors, nurses, sanitation workers, and cashiers at groceries are the daily topics on the surface of public discourses (Lindhoff, 2020). In a nutshell, the societal conscience for resilience to survive was followed as a task force at daily basis. The foresight was at the same time the hindsight, and the opposite way around.

\section{Refugee as Approver}

A refugee in Frankfurt might be seen as an approver. When talking about Covid-19 pandemic, which is in liaison with life and death, the individual refugee, who came to here, epitomizes by his or her will to take the undetermined burden to migrate. In the 
current situation the permission for the legal status is getting difficult if a foreigner seeks shelter as a refugee and he or she is not from the European Union.

Not later than this outbreak of Covid-19 pandemic the habit of stockpiling dominated the societal media debate in Germany about people's motives of panic-buying toilet tissue, germicide, and noodles. This is the embodiment of a certain stereotype of syncope of the vast majority of Germany.

But for all that, the refugee is always in permanent danger being deported back, as it was reported by media. In this sense a 37 year old female Syrian is complaining: "We as refugees are living in a trauma and post-trauma condition. Whether we know if we are staying here, we are allowed to, or we should re-migrate to Syria. In spite of this, why I should be afraid to die. Do you or the people in Frankfurt fear to die?"

\section{Conclusion}

In Germany's neighboring country France, the French intellectual radio "France Culture" dedicated a whole series of radio broadcast to "Coronavirus, Une Conversation Mondiale" (English: Corona Virus, A Global Conversation) (France Culture, 2020): Once more, the legendary stroke of genius of Albert Camus "La Peste" (English: The Plague) was debated in this radio station as the historical legacy of 1947. As Germany's western neighbor, in times or "opportunities of crisis" France (44\%) was evaluated by "a representative survey on German attitudes to foreign policy" as the most important partner for Germany, while the USA (10\%), China (6\%) and Russia (4\%) got not in sum half of the votes in comparison to France (Körber Stiftung, 2020). The new shape of the world seems to include one more important factor after Covid-19 pandemic, which is on the one hand the "politization of health issues", and on the other the "sanitarization of politics".

This Covid-19 pandemic was the watershed at glocalized platform without any slight announcement. The virtual offline world transcended to the real life, whereas the daily vibrant life was because of the lockdown to be for a time alone. Forced seclusion from the public space at home was the solution to the Frankfurt citizen.

The refugees in this study were concerned, but not as that much as expected. The common attitude and stance were that the interviewed refugees compared their current situation in Frankfurt with their home countries: The zone of freedom (Frankfurt) vs. the zone of armed conflicts. Attention should be paid to the cast that Frankfurt is not an ordinary city, which all of the interviewees recognized. Principally, the transcultural distinctive side of Frankfurt at daily basis was pointed out (Alam, 2019).

In the public sphere of influence of the German newspaper "Die Zeit" the eminent 90 years old Juergen Habermas was discussing in a conversation with the professor for legal theories Klaus Guenther about the significance of human dignity, its protection 
and the basic limits of rights in the German constitution (Habermas, Guenther, 2020). More or less, both argued that even basic rights are not infinite.

To recommend only one point: There is no in-depth long-running scientific investigation about refugees in Frankfurt to gain more knowledge how they would obey the rules, if experiencing or re-experiencing situations of crisis without arms. It is necessary to investigate more on refugees with a preemptive outlook who belong to the more vulnerable social groups.

On a final note, the Covid-19 pandemic infectious disease prompted in many fields to a certain extent legal, political, societal, individual, gender, economical and digital debates through the lens of health.

\section{References}

[1] Alam, H., (2016). Menschen- und Flüchtlingsrechte im Iran, 2. überarbeitete \& erweiterte Auflage, Nordhausen: Bautz Verlag, pp. 167-197.

[2] Alam, H., (2019). Frankfurt am Main, transkultureller Alltag in der Supervielfalt, Retrieved May 2, 2019, from https://www.migazin.de/2019/11/12/frankfurt-am-main-transkulturelleralltag-in-der-supervielfalt/

[3] Alberer, M., Malinowski, S., Sanftenberg, L., \& Schelling, J. (2018). Notifiable infectious diseases in refugee and asylum seekers: experience from a major reception center in Munich, Germany, Retrieved May 6, 2020, from https://doi.org/10.1007/s15010-018-1134-4

[4] Barkin, N., (2020). In the Post-Pandemic Cold War, America is Losing Europe: In the growing confrontation with China, Europe is starting to take sides- just not America's. Retrieved May 19, from https://foreignpolicy.com/2020/05/19/coronavirus-pandemic-europeopinion-polls-united-states-china-losing/?fbclid=IwAR3jAD9uKzKHN4kRJNcg-fIKiIC2WN4Zx3caWROaYPg2HKt3rUj3fEFtEk

[5] Bathke, B., (2019). Refugees with own income pay up to €930 rental fees in shared accomodation in Germany, Retrieved May 6, 2020, from https://www.infomigrants.net/en/post/18824/refugees-with-own-incomepay-up-to-930-rental-fees-in-shared-accommodation-in-germany

[6] Deutscher Bundestag, (2014). Retrieved May 7, 2020, from https://www.bundestag.de/dokumente/textarchiv/2014/kw45_regierungs sitz_bonn-337836

[7] France Culture, (2020), Coronavirus, Une Conversation Mondiale. Retrieved May 8, 2020, from https://www.franceculture.fr/theme/coronavirus-uneconversation-mondiale

[8] Georgiou, M., Zaborowski, R., (2017). Media Coverage of the "Refugee Crisis": A Cross-European Perspective, In: Council of Europe Report, Retrieved May 5, 2020, from https://rm.coe.int/1680706b00 
[9] Habermas, J., Guenther, K., (2020). Kein Grundrecht gilt grenzenlos. Retrieved May 9, 2020, from https://www.zeit.de/2020/20/grundrechtelebensschutz-freiheit-juergen-habermas-klaus-guenther

[10] Hamideh, A., (2018). Financial Crisis 2020. Retrieved May 8, 2020, from https://www.researchgate.net/publication/329936117_Financial_crisis_20 20

[11] Harari, Y. N., (2020). Will coronavirus change our attitudes to death? Quite the opposite', Retrieved April 25, 2020, from

https://www.theguardian.com/books/2020/apr/20/yuval-noah-harariwill-coronavirus-change-our-attitudes-to-death-quite-the-opposite

[12] Hessenschau, (2020a). Retrieved May 8, 2020, from https://www.hessenschau.de/panorama/coronavirus--8877-corona-faelle405-tote--theater-bleiben-noch-zu--bouffier-sieht-wieder-stunde-nullgekommen-,corona-hessen-ticker-100.html

[13] Hessenschau, (2020b). Retrieved May 8, 2020, from https://www.hessenschau.de/wirtschaft/corona-krise-schlaegt-massiv-aufden-arbeitsmarkt-durch,arbeitsmarkt-arbeitslose-kurzarbeit-100.html

[14] Historisches Museum Frankfurt, (2020). Frankfurt = heimliche Hauptstadt?, Retrieved May 7, 2020, from https://historisches-museumfrankfurt.de/en/schneekugel/hauptstadt

[15] Holtfrerich, C.-L., (1999). Finanzplatz Frankfurt, Von der mittelalterlichen Messestadt zum europäischen Bankenzentrum. München: C. H. Beck, pp. 3069.

[16] International City of Refuge Network, ICORN, (2006). Retrieved May 7, 2020, from https://www.icorn.org/city/frankfurt

[17] Jüdische Orte in Frankfurt am Main, (2011). Retrieved May 7, 2020, from http://www.juedisches-frankfurt.de/orte/erinnerungsorte-zu-annefrank\#fn-2

[18] Katz, B., Noring, L., \& Garrelts, N., (2016). Cities and Refugees- The German Experience, In: A discussion paper prepared for the Brookings Institution Forum, "Cities and refugees: The European response" during the United Nations General Assembly 2016, Retrieved May 4, 2020, from https://www.brookings.edu/wpcontent/uploads/2016/09/cs_20160920_citiesrefugees_germanexperience. pdf

[19] Körber Stiftung, (2020). The Berlin Pulse 2020 - Special Edition: German Foreign Policy in Times of Covid-19, Retrieved May 20, from https://www.koerber-stiftung.de/fileadmin/user_upload/koerberstiftung/redaktion/the-berlin-

pulse/pdf/2020/Koerber_TheBerlinPulse_Sonderausgabe_Doppelseiten_202 00518.pdf

[20] Lindhoff, A., (2020), Systemrelevant und unsichtbar: Corona-Krise zeigt die Doppelmoral gegenüber Migrantennen und Migranten. Retrieved May 8, 
2020, from https://www.fr.de/panorama/corona-krise-systemrelevantunsichtbar-migranten-arbeitskraefte-video-klagt-doppelmoral-zr13751080.html

[21] Lohde-Reiff, R., (2003). Frankfurt ist Anderswo: Die globale Stadt im Urteil ihrer Bewohner. Kassel University Press. Pp. 59-78.

[22] Neis, H.J., Meier, B., \& Furukawazono, T., (2018). Welcome City: Refugees in Three German Cities, In: Urban Planning, 2018, Volume 3, Issue 4, Pages 101-115 114.

[23] Polizeiliche Kriminalstatistik, (2018). Retrieved May 7, 2020, from https://www.polizei.hessen.de/icc/internetzentral/nav/5dc/binarywriters ervlet?imgUid=4e52055f-3d17-2961-a1de-

42920149b809\&uBasVariant=11111111-1111-1111-1111-111111111111

[24] Robert Koch Institut, (2020). Retrieved May 8, 2020, from https://www.rki.de/DE/Content/InfAZ/N/Neuartiges_Coronavirus/Situatio nsberichte/Gesamt.html

[25] Setzepfandt, C., (2020). Corona-Spezial: Virtuelle Stadtführungen "Stadt@Home" - Ein Rundgang über den Frankfurter Hauptfriedhof mit Christian Setzepfandt, Retrieved May 21, from https://www.frankfurterstadtevents.de/Themen/Aktionsartikel/Corona-Spezial-VirtuelleStadtfhrungen-StadteventsHome_20016054/

[26] Stadt Frankfurt am Main, (2020a). Retrieved May 6, 2020, from https://fluechtlinge-frankfurt.de/ueber-die-stabsstelle/

[27] Stadt Frankfurt am Main, (2020b). Retrieved May 6, 2020, from https://fluechtlinge-frankfurt.de/aktuelle-zahlen/

[28] The White House, (2020). Fact Sheet: President Donald J. Trump Is Demanding Accountability From the World Health Organization. Retrieved May 8, 2020, from https://www.whitehouse.gov/briefingsstatements/president-donald-j-trump-demanding-accountability-worldhealth-organization/

[29] Vertovec, S., (2013). Frankfurt - Die Vernetzung der Kulturen, Göttingen: Max-Planck-Institut zur Erforschung multireligiöser und multiethnischer Gesellschaften. Retrieved April 29, 2020, from https://www.mpg.de/805787/Multikulturelle_Vielfalt

[30] Wiggershaus, R. (2008). Die Frankfurter Schule: Geschichte, theoretische Entwicklung, politische Bedeutung. München: Dt. Taschenbuch Verlag, pp. 28-59.

[31] Wirtschaftsförderung Frankfurt, Coronavirus - Informationen zur Hilfe für Unternehmen, (2020). Retrieved May 8, 2020, from https://frankfurtbusiness.net/coronavirus-informationen-zur-hilfe-fuer-unternehmen/ 